Article

\title{
Increasing Access to Electricity: An Assessment of the Energy and Power Generation Potential from Biomass Waste Residues in Tanzania
}

\author{
Zahida Aslam ${ }^{1, *}, \mathrm{Hu} \mathrm{Li}^{2}{ }^{\mathbb{D}}$, James Hammerton ${ }^{2}$, Gordon Andrews ${ }^{2}$, Andrew Ross ${ }^{2}$ and Jon C. Lovett ${ }^{3}$ \\ 1 School of Chemical and Process Engineering and Centre for Doctoral Training in Bioenergy, University of \\ Leeds, Leeds LS2 9JT, UK \\ 2 Faculty of Engineering, School of Chemical and Process Engineering, University of Leeds, Leeds LS2 9JT, UK; \\ H.Li3@Leeds.ac.uk (H.L.); J.M.Hammerton@leeds.ac.uk (J.H.); G.E.Andrews@leeds.ac.uk (G.A.); \\ A.B.Ross@leeds.ac.uk (A.R.) \\ 3 School of Geography, University of Leeds, Leeds LS2 9JT, UK; J.Lovett@leeds.ac.uk \\ * Correspondence: pmzba@leeds.ac.uk
}

check for

updates

Citation: Aslam, Z.; Li, H.;

Hammerton, J.; Andrews, G.; Ross, A.;

Lovett, J.C. Increasing Access to

Electricity: An Assessment of the

Energy and Power Generation Potential

from Biomass Waste Residues in

Tanzania. Energies 2021, 14, 1793.

https://doi.org/10.3390/en14061793

Academic Editors: Tapas Mallick and Biagio Morrone

Received: 10 February 2021

Accepted: 17 March 2021

Published: 23 March 2021

Publisher's Note: MDPI stays neutral with regard to jurisdictional claims in published maps and institutional affiliations.

Copyright: (c) 2021 by the authors. Licensee MDPI, Basel, Switzerland. This article is an open access article distributed under the terms and conditions of the Creative Commons Attribution (CC BY) license (https:// creativecommons.org/licenses/by/ $4.0 /)$.

\begin{abstract}
Tanzania has a high rural population, of which many rely on off-grid diesel generators to produce electricity. The focus of this paper is to assess if the waste biomass residues in Tanzania have sufficient energy potential to produce renewable electrical energy for small-scale electricity generation using off-grid diesel generators coupled with anaerobic digestion (AD) and/or gasification. The gaseous fuel produced can then be used to substitute diesel fuel used in small-scale dual fuel diesel gen-sets; thus, providing more affordable electricity whilst reducing dependency on fossil fuels. The biomass waste streams estimated are those arising from agriculture, forestry, livestock, and urban human waste. To answer this question, the energy potentials of each of these biomass waste streams are quantified, followed by further calculations to determine the electricity generation capacity per stream based on overall efficiencies of 10 and $25 \%$. The results show that combined these waste streams have an energy potential of 385 PJ (for the base year of 2018) generated from 26,924 kilotonnes (kt). Collectively, these residues can produce at least 1.2 times the electricity generated nationally in 2018 using AD and gasification coupled with a diesel gen-set engine.
\end{abstract}

Keywords: biomass; energy potential; electrification; gasification; anaerobic digestion; Tanzania

\section{Introduction}

Access to electricity is a globally recognised requirement to eradicate poverty and has been chosen by the United Nations as a "sustainable development goal", which has been defined as "Goal 7: ensure access to affordable, reliable, sustainable, and modern energy for all" [1]. Hence, access to electricity is pivotal in achieving this as many basic human activities rely solely on electricity as other forms of energy cannot be used as a substitute. Such examples include lighting, refrigeration, running of household appliances, etc.

Tanzania is considered to be a "least developed country" by the OECD Development Assistance Committee (DAC) and has a large growing population of 56.32 million as recorded in 2018 [2]. Only 35.6\% of the total population have access to electricity [3]; this equates to over 36 million people living in Tanzania without any access to electricity.

In 2018, Tanzania had a rural population of $66.2 \%$, with only $18.8 \%$ of this rural population having access to electricity [4,5]. Thus, lack of access to clean modern energy supplies is most acute in rural areas. Moreover, even for those with electricity, the supplies are intermittent and unreliable [6,7].

Many African governments, including Tanzania, recognise that one of the most economical methods of increasing electrification rates (especially within rural areas) is not by network grid expansions, but by utilising renewable energy sources, specifically mini and off-grid solutions [7]. For example, Bertheau et al. [8] consider that incorporating 
photovoltaic (PV) and storage systems with existing diesel-based off grid systems can lead to significant cost reductions in electricity generation by this method in Tanzania. To facilitate this, favourable governmental policies, economics, and training are required to facilitate the uptake of renewable energy opportunities. In general, energy policies are quite well developed in Tanzania; however, some sectors require further development, particularly, the biomass and off-grid sectors [9]. Government policies and agencies exist in Tanzania which support rural electrification and the use of local renewable energy sources. The Rural Energy Agency (REA) was established in 2005 to focus on rural electrification. In conjunction with other organisations, the REA has promoted off-grid electrification projects as decentralised solutions ranging from 1 to 10 MW [9]. The Rural Electrification Program Prospectus developed by the REA states that for rural communities, the focus is to increase electrification by using off-grid technologies where isolated mini-grids are supplied by renewable energy sources or hybrid systems. The focus is on mini-grids associated with hydro and biomass gasifiers plants or hybrid PV systems to settlements/villages/households located $10 \mathrm{~km}$ or more from the main grid [9]. To date, $6 \mathrm{MW}$ of solar PV has been installed in Tanzanian communities [9]. Other approved small power producer agreements for isolated mini-grids were associated with solar (2 MW), three biomass plants (5.1 MW), and 2 hydropower projects [10]. Figure 1 shows that the existing power grid connects more densely populated urban regions, whereas mini-grids are sparsely distributed across rural areas of Tanzania [11].

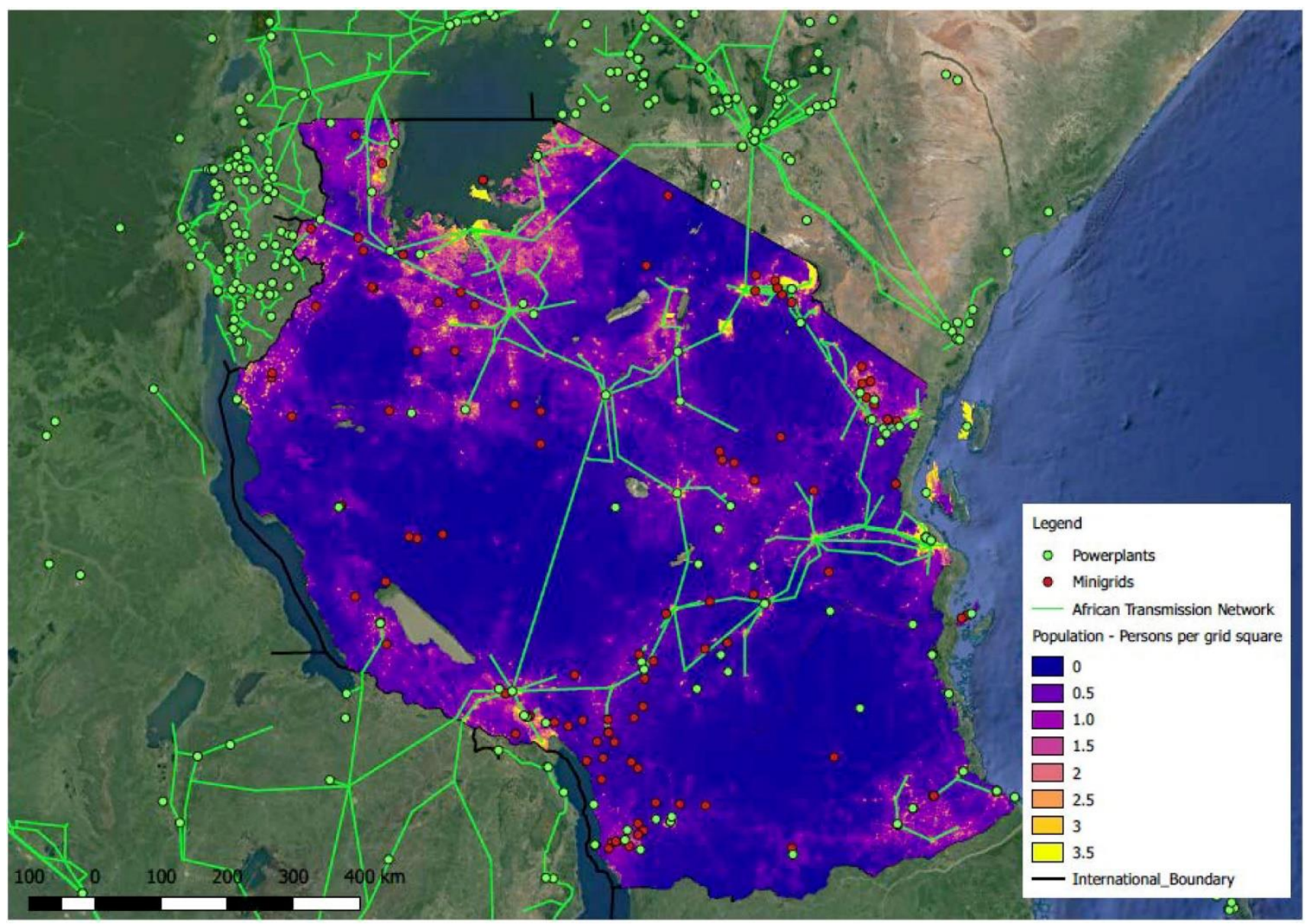

Figure 1. Population distribution in Tanzania in relation to existing power grid and mini grids [11]. 
For those relying on electricity generated by off-grid diesel generators the fuel costs are high, so these off-grid systems have a substantially higher running cost per kWh than gridconnected systems $[7,8,12]$. In 2013, it was estimated that energy generated nationally from off-grid private diesel-based generation was $300 \mathrm{MW}[9,12]$. High cost and dependency on fossil fuels of off-grid diesel generators are impediments to sustainable and economic development, especially in rural areas [8]. Moreover, $80 \%$ of Tanzanians still utilise biomass (firewood, charcoal, etc.) as a source of energy [13]. Whether burnt indoors or outdoors, the smoke produced is a pollutant linked to adverse health, in particular respiratory diseases which disproportionately affect women and children [12]. Those residing in the cooler climate of the southern highland regions of Tanzania, often cook indoors, thus increasing exposure to smoke pollutants [14]. This study looks at the potential for producing electricity by utilising existing equipment commonly used for small-scale electricity generation, i.e., the "diesel generator/diesel gen-set" by substitution of the diesel fuel with gaseous fuel and so running the engine in a dual fuel mode.

The two electricity generation technologies evaluated for this purpose are gasification and anaerobic digestion (AD). The feedstock for the generation of gaseous fuel is from the processing of the waste residues streams arising from agriculture, forestry, livestock, and urban human waste. Availability of feedstock and suitability of the technologies are considered viable for this region [15-17] and can be coupled with existing small-scale electrification equipment. The agricultural and forestry residues can be processed using gasification technology to produce an energy-rich combustible gas called syngas (producer gas). The livestock and urban waste residues can be processed using AD to produce biogas. $\mathrm{AD}$ technology is more feasible for processing the selected waste streams due to their high moisture content. These gases can be fed into a dual fuel internal combustion engine or an adapted diesel internal combustion engine (ICE) as a substitute for diesel. Production of electrical energy by utilisation of biomass waste residues can provide more affordable and renewable energy due to the decrease in diesel consumption, thus decreasing dependency on fossil fuels whilst increasing access to electricity, especially in rural locations.

Biomass waste residues are underutilised and/or wasted in this region [18]. Open dumping and/or open burning are common methods of waste treatment and disposal in such developing countries $[19,20]$. The Food and Agricultural Organisation (FAO) estimated that in 2018 burning crop residues (from maize, rice, sugar cane, and wheat) generated $379.3 \mathrm{kt}$ of $\mathrm{CO}_{2}$ equivalent emissions in Tanzania [21]. With the majority of these arising from maize alone (approx. 85\%) [21]. Using waste biomass as a direct source of "solid biofuels" for energy generation is difficult due to the variable nature of these residues in terms of size, form, moisture content, and low density, etc [22]. Pre-treatment methods such as pelleting, briquetting, and torrefaction are becoming commonly used to overcome these issues thereby increasing the concentration, density, and heating values [22]. However, this paper will focus on methods of using such waste streams in the absence of such enhancement techniques.

Utilising these waste streams for gasification [15] or using AD technology $[17,20]$ in this manner also provides an alternative waste management solution, thereby mitigating environmental and health issues associated with the current disposal methods. A small study conducted in northern rural Tanzania indicated that some of the benefits gained by those who adopting $\mathrm{AD}$ technology included an increase in farm incomes as well as a reduction in greenhouse gas emissions [23], whilst providing flexibility as can be used on a small or large scale $[16,24]$. Furthermore, using biogas for cooking mitigates the pollutant issues associated with low-grade fuels used in inefficient cookstoves. Thus, in summary, utilising biomass waste residues as feedstock for gasification or AD to produce small-scale renewable energy has additional benefits, especially to rural communities. These include environmental, social, and economic benefits [15,17,24].

Other alternatives to produce renewable power from these gaseous fuels involve using a dedicated gas engine or modification of existing internal combustion engines. Examples 
of some of the modifications required involve changes in the compression- ratio, the spark ignition time, and the air/gas mixing systems [25].

Anaerobic digestion technology combined with gas or dual fuel engines is well developed and globally used for energy production [26]. Its success in "newly industralised countries" has been enhanced by government support in the form of policies, subsidies, tax incentives, and/or feed-in tariffs $[16,26]$. Transferring this success to Africa is deemed as potentially promising if the various barriers can be overcome. One of the initial barriers to uptake, (especially on the smaller scale of $1-500 \mathrm{~kW}$ ), revolves around the initial investment as developers may find these less financially attractive $[16,26,27]$.

Gasification coupled with an internal combustion engine for energy production has penetrated various countries over a range of scales, especially in India [26,28]. Small-scale gasification units $\left(<100 \mathrm{~kW}_{\mathrm{e}}\right)$ are an attractive choice of technology for producing electricity from agricultural waste residues at a reasonable level of efficiency [26]. Small-scale biomass gasification units have the benefit of lower capital costs, thus making them more economically viable. Bhattacharya [29] states that to overcome the barriers associated with this technology on a medium to large scale, using small-scale units that are locally fabricated which can be successfully operated by operators with limited technical experience is the best solution. However, issues remain in terms of the reliability of these units based upon problems associated with a lack of technical expertise as well as with gas quality. This is due to the high tar content of the syngas produced and contamination of cleaning water $[26,28]$. There are many advantages and disadvantages with both processes when used for small-scale power generation with ICE. For gasification, the waste biomass residues can be easily collected and stored as are a natural by-product during harvesting or processing. Whereas for biogas, the residues may be dispersed over larger areas and must be manually collected and stored appropriately for the generation of biogas. Hence gasification is better suited for larger volumes of biomass residues.

This article firstly quantifies the raw energy potential (EP) of each of these four waste streams. A similar study incorporating all four waste streams does not appear to be available in the literature for Tanzania. Lyakurwa [30] quantified the energy potential from the ten main crops grown in Tanzania and that generated from livestock waste. However, the moisture content of the crop residues was not accounted for. Lyakurwa [30] concluded that utilisation and management of both these residues in the correct manner could generate renewable electricity, thereby increasing access to electricity thus reducing fossil fuel consumption. Terrapon-Pfaff [31] calculated the energy potential arising from the biomass residues from five key commercial crops in Tanzania. This study concluded that utilising certain agricultural process residues for energy generation could secure the energy supply as well as improve the sustainability of land-use practices in Tanzania. Kusekwa [18] identified all four waste streams as having huge energy potential with the potential to be realised using gasification or AD. Furthermore, he stated that converting such biomass residues into energy provides a commercial value to the biomass of interest; however, he did not quantify the energy potential of these streams.

When utilising biomass in gasification with an internal combustion engine for power generation, the overall efficiencies are dependent on the size of the power plant [32,33]. A review of the literature based on the use of syngas in ICE by Martinez et al. [34] shows that the overall efficiencies of downdraft gasification units coupled with diesel engines (sized 12 to $20 \mathrm{~kW}$ ) varied from 11.69 to $25.0 \%$ [34-38]. Losses are experienced for various reasons including the thermal efficiency of the engine; however, a further factor that impinges on the overall efficiency is the calorific value $(\mathrm{CV})$ of the syngas produced. This in turn is dependent on the quality and type of the biomass feedstock and the gasification operational parameters. Dual fuel operation diesel/biogas engines (1500 RPM) used for small-scale electricity generation typically have a maximum thermal efficiency of $23 \%$ [39]. A summary of some of the overall efficiencies seen in dual fuel engines for electricity generation is summarised in Table 1. 
The main objective of this paper is to quantify the energy potential of each waste stream. The base year of 2018 was chosen due to the range of full data available for this period. The energy potential available from these waste residue streams is then to be converted into actual electricity generated using either AD and/or gasification. The value of this potential can then be realised by comparing it to the actual electricity generated nationally during the same year (2018). This goes to highlight how renewable and sustainable electricity can be generated whereby reducing the dependence on fossil fuels.

Table 1. Overall efficiency of some dual fuel systems for electricity generation.

\begin{tabular}{cccc}
\hline Power $\mathbf{( k W )}$ & Overall Efficiency (\%) & Dual Fuel Type & Reference \\
\hline$<10$ & 10 & Gasification/diesel & {$[32]$} \\
$10-100$ & $10-20$ & Gasification/diesel & {$[32]$} \\
$<50$ & 20 & Gasification/diesel & {$[33,40,41]$} \\
$25-50$ & $>25$ & Gasification/diesel & {$[33,40,41]$} \\
100 & 18 & Gasification/diesel & {$[33,40]$} \\
$12-16$ & $21-24$ & Gasification/diesel & {$[34,35]$} \\
$15-20$ & 25 & Gasification/diesel & {$[34,37]$} \\
11.44 & 11.69 & Gasification/diesel & {$[34,36]$} \\
17.5 & 16.6 & Gasification/diesel & {$[34,38]$} \\
58.4 & $11.7-20.7$ & Gasification/diesel & {$[42]$}
\end{tabular}

\section{Materials and Methods}

Based on the literature reviewed, for this paper, we calculate the overall efficiency of these dual fuel systems (from biomass to net electricity) at a lower and upper end. Overall efficiency values for this range were chosen at 10 and $25 \%$ based on the values quoted in the open literature, as shown in Table 1. This range is also suitable for power generation when processing biomass waste using AD. Dual fuel operation diesel/biogas engines have a thermal efficiency of 23\% [39]. Hence to derive the final "Net $G W h_{e}$ " value, any transmission, and distribution $(T \mathcal{E} D)$ losses have then to be considered. The 'Net $G W h_{e}$ ' calculated for the agricultural, forestry, and urban human waste stream was derived using Equation (1). For the livestock waste stream, the Net $G W h_{e}$, was calculated using Equation (2) (based on microgrid losses of 10\%) [43].

$$
\begin{aligned}
& \text { Net GWhe }=\text { Gross GWhe } \times\left(\frac{\text { overall efficiency }}{100}\right) \times\left(\frac{100-\% T \& D \text { losses }}{100}\right), \\
& \text { Net GWhe }=\text { Gross GWhe } \times\left(\frac{\text { overall efficiency }}{100}\right) \times\left(\frac{100-\% \text { microgrid losses }}{100}\right)
\end{aligned}
$$

\subsection{Agricultural Residues}

For this calculation, values for the Residue to Product Ratio (RPR), Moisture content $(M C)$, Fraction Availability (FA), and Lower Heating Values ( $L H V)$ were obtained for the crops of interest. The $R P R$ is dependent on many variables which include processing and harvesting techniques, type/variety of crop, growing conditions such as the amount of water, nutrients and fertiliser used, and so forth [44]. Hence the values quoted in the open literature vary from study to study. As with other biomass assessment studies available in open literature, the more commonly used figure from literature was used. Further, not all the agricultural residues produced can be used or are available for bioenergy purposes due to competing uses such as animal bedding, fodder, fertiliser, briquette manufacture, etc. Again, literature sources quote variable figures for the $\%$ availability or a $F A$ factor. For this study, the most common/utilised FA figure for this region was used. To calculate the energy potential from these residues, data from the FAO was collated for the base year of 2018 [45]. This base year provided the most current complete data set. The realistic 
electricity generation potential from all the residue streams was calculated based on an overall power potential generation efficiency of $10 \%$ and $25 \%$ as shown in Table 1 [32-42].

For the agricultural, forestry, and urban human waste residues, the $T \mathcal{E} D$ losses were also accounted for. For the base year of 2018, these losses stood at 16.9\% [46]. Some crops have been excluded as either very small quantities were produced, or there is little information available on open literature for the values of $R P R, M C, F A$, or $L H V$. Agro-based woody crop residues have also been excluded such as prunings from various trees.

The data used for calculations for the energy potential arising from key agricultural, perennial plantation and oil seed crops are shown in Tables $2-4$.

Table 2. Perennial plantation crop residue data.

\begin{tabular}{cccccc}
\hline Crop & Type & RPR & $\boldsymbol{F A}$ & MC (\%) & LHV (MJ/kg) \\
\hline Cashew & Husks & $2.10[31,47]$ & $0.17[31]$ & $6.5[31,47]$ & $14.9[31,47]$ \\
\hline Coffee & Husks & $0.25[31,47]$ & $1.0[31]$ & $15[47,48]$ & $12.38[47,48]$ \\
\hline Coconut & Husks & $0.419[47,48]$ & $0.884[49]$ & $10.3[47,48]$ & $18.62[47,48]$ \\
\hline Coconut & Shells & $0.12[47,48]$ & $0.75[47,50,51]$ & $8.7[47,48]$ & $18.09[47,48]$ \\
\hline Oil, Palm & Shell & $0.065[48,52]$ & $0.625[49]$ & $10[48,52]$ & $18.83[48,52]$ \\
\hline Oil, Palm & Fibre & $0.13[48,52]$ & $0.80[50,52,53]$ & $40[48,52]$ & $11.34[48,52]$ \\
\hline Oil, Palm & Empty bunches & $0.23[48,52]$ & $0.614[49]$ & $50[48,52]$ & $8.16[48,52]$ \\
\hline Soybean & Straw & $2.5[47,48]$ & $0.767[49]$ & $15[47,48]$ & $12.38[47,48]$ \\
\hline Soybean & Pods & $1[47,48]$ & $0.767[49]$ & $15[47,48]$ & $12.38[47,48]$ \\
\hline Sorghum & Straw & $1.25[47,48]$ & $0.766[49]$ & $15[47,48]$ & $12.38[47,48]$ \\
\hline Seed cotton & Stalk & $3.743[47,50]$ & $0.8[54]$ & $12[47,50]$ & $13.07[49]$ \\
\hline Sisal & Pulp & $24[31,47,55]$ & $1[31]$ & $91 *[31,47]$ & $14.4[31,47]$ \\
\hline Sisal & Ball/fibre & $3.55^{*}[30]$ & $1^{* *}[31]$ & $711^{* *}[55]$ & $14.4 *[31,47]$ \\
\hline
\end{tabular}

* Average value used. ${ }^{* *}$ Assumed as per sisal pulp. ${ }^{* * *}$ Assumed (by difference).

Table 3. Agricultural crop residue data.

\begin{tabular}{|c|c|c|c|c|c|}
\hline Crop & Type & $R P R$ & $F A$ & $M C(\%)$ & $L H V(\mathrm{MJ} / \mathrm{kg})$ \\
\hline \multirow{2}{*}{ Cassava } & Stalks & $\begin{array}{c}0.062 \\
{[47,48,56]}\end{array}$ & $0.2[50,57]$ & $15[47,48]$ & $17.5[47,48]$ \\
\hline & Peelings & $0.25[56]$ & $0.3[56]$ & $50[48]$ & $10.61[56]$ \\
\hline \multirow{2}{*}{$\begin{array}{c}\text { Groundnuts } \\
\text { including } \\
\text { shells }\end{array}$} & Shells & $0.477[47,48]$ & $1.0[56]$ & $8.2[47,48]$ & $15.66[47,48]$ \\
\hline & Straw & $2.3[48,56]$ & $0.5[50,58,59]$ & 15 [48] & $14.4[56]$ \\
\hline \multirow{3}{*}{ Maize } & Straw/stalk & $2.0[48,50,58]$ & $0.7[48,50,58]$ & $15[48,50,58]$ & $\begin{array}{c}19.66 \\
{[48,50,58]}\end{array}$ \\
\hline & Cob & $0.273[47,48]$ & 0.863 [49] & $7.53[47,48]$ & $16.28[47,48]$ \\
\hline & Husk & $\begin{array}{c}0.2 \\
{[48,50,56,60]}\end{array}$ & $0.6[50,56,60]$ & $\begin{array}{c}11.11 \\
{[50,56,60]}\end{array}$ & $\begin{array}{c}15.56 \\
{[50,56,60]}\end{array}$ \\
\hline Millet & Straw/stalk & $1.75[47,48]$ & $0.8[47,50]$ & $15[47,48]$ & $12.39[47,48]$ \\
\hline \multirow{2}{*}{ Rice, paddy } & Straw & $1.757[47,48]$ & 0.684 [49] & $12.71[47,48]$ & $16.02[47,48]$ \\
\hline & Husk & $0.267[47,48]$ & 1.0 [49] & $12.37[47,48]$ & $19.33[47,50]$ \\
\hline \multirow[t]{2}{*}{ Sugar } & $\begin{array}{l}\text { Top and } \\
\text { leaves }\end{array}$ & $0.30[48,61]$ & 0.986 [49] & $10[50,61]$ & $\begin{array}{c}15.81 \\
{[48,50,61]}\end{array}$ \\
\hline & Bagasse & $0.29[47,48]$ & $0.8[47,50]$ & $50[47,50,57]$ & $18.10[47,48]$ \\
\hline
\end{tabular}


Table 4. Oilseed crop residue data.

\begin{tabular}{ccccc}
\hline Oilseed Crop & $\begin{array}{c}\text { \% Oil from } \\
\text { Seed }\end{array}$ & Waste Type & $\begin{array}{c}\text { Waste (Based on } \\
\text { \% of Seed/Bean) }\end{array}$ & LHV (MJ/kg) \\
\hline Sesame & $50[62]$ & Cake & $35^{*}[63]$ & $9.54^{* *}[64-66]$ \\
\hline Sesame & & Hull & $15[63,67]$ & $18.22[68]$ \\
\hline Cotton & $12[54]$ & Cake & $50[54]$ & $18.6[69]$ \\
\hline Cotton & & Hull & $26[54]$ & $18.01[70,71]$ \\
\hline Sunflower & $40[72]$ & Cake & $35[73]$ & $15.86[72]$ \\
\hline Sunflower & & Hull & $25[73]$ & $19.5[74]$ \\
\hline${ }^{*}$ Assumed (by difference). ${ }^{* *}$ Average value calculated from the lit source.
\end{tabular}

The energy potential of the agricultural residues ( $\left.E P_{\text {residue }}\right)$ was calculated using the method by Bhattacharya et al. [75] as shown in Equations (3) and (4). In Equation (3), ARG is the amount of a residue generated annually on a dry basis $\left(\mathrm{t} \mathrm{yr}^{-1}\right)$, and $A H$ is the annual harvest of the crop or product (t). In Equation (4), the $E P_{\text {residue }}$ represents the total energy potential of each residue $\left(\mathrm{J} \mathrm{t}^{-1}\right)$, the sum of the $S A F$ and $E U F$ correlates to the fractional availability, whereby $S A F$ represents the surplus availability factor, and the EUF represents the energy use factor. Both factors are dimensionless.

$$
\begin{gathered}
A R G=\Sigma(R P R \times A H) \\
E P_{\text {residue }}=A R G \times(S A F+E U F) \times L H V_{\text {residue }}
\end{gathered}
$$

\subsection{Forestry Waste}

The logging industry produces significant residues, some of which are considered as waste and are usually left to decompose. Some of the forestry residues have competing uses and are therefore unavailable for bioenergy purposes. Thus, an FA factor is applied when carrying out the potential energy calculations as quoted in the literature $[48,50]$. The energy potential was considered from this forestry industry using production data from the FAO, based on 1,616,000 $\mathrm{m}^{3}$ of non-coniferous roundwood and $15,000 \mathrm{~m}^{3}$ of plywood [76].

This data from the FAO is quoted in volume (solid volume), and for the EP calculations, a mass value is required. Thus, to convert, a basic density value for each type of residue stream was required. The basic density figure for the residues arising from the solid wood and plywood was calculated based on an oven-dried (od) weight over a green volume. This average basic density was calculated based on the following facts [77]:

- The most important industrial plantation species are various species of pines, cypress, eucalyptus, and teak.

- Most of the commercial wood grown $(\sim 85 \%)$ is dominated by softwoods.

- Softwood plantations cover approximately $85 \%$ of the gross plantations area. This is dominated by varies species of pines.

- The remainder (15\%) will be assumed to be made of various hardwood species.

Thus, an average figure for the overall basic density was calculated using known values for the species of interest present in Tanzania [77]. These values are shown in Tables A1 and A2 of the Appendix A [78-97]. The average figure calculated for the basic density of solid wood was $471 \mathrm{~kg} / \mathrm{m}^{3}$ based on a ratio of 0.85:0.15 being applied (softwood to hardwoods).

For the sawdust residues, a fixed value of $220 \mathrm{~kg} / \mathrm{m}^{3}$ was used. This is the basic density (od/green volume) data for the sawdust residues derived from a mix of pine and hardwood [98]. $L H V$ figures on a dry ash-free (daf) used in the calculation were obtained from literature as shown in Table A5 in the Appendix A [99-103]. In some cases, a range was used for the calculations due to the range of values quoted in the literature. 


\subsection{Energy from Animal Waste}

Energy potential from the animal waste produced from five key animals was considered for this study: cattle, goats, chicken, pigs, and sheep. Collecting and processing such livestock waste via $\mathrm{AD}$ allows the organic content of the waste to be realised by the production of biogas.

Biogas produced can be burned directly to produce energy or can be upgraded/cleaned to remove any unwanted gases and impurities to produce biomethane.

Data regarding the number of live animals for the base year was obtained from the FAO database [104]. Data from open literature from 2010 suggests that the population of dairy cattle during this period only makes up 3.24\% of the total cattle population [105], and this will be used in these calculations. According to Sajjakulnukit et al. [49], the cattle type influences the amount of manure produced daily, with dairy cattle producing three times more daily waste than beef or buffalo. The energy potential from the animal manure that is recoverable $\left(E P_{\text {manure }}\right)$ was calculated using Equations (5)-(7) as shown below [75]. In Equation (5), the $A B P_{\text {manure }}$ is the amount of biogas from recoverable manure $\left(\mathrm{Nm}^{3} / \mathrm{yr}\right), E P_{\text {manure }}$ is the energy potential of the recoverable manure $(\mathrm{J} / \mathrm{yr})$ and the $L H V_{\text {biogas }}$ represents the lower heating value of biogas $\left(\mathrm{J} / \mathrm{m}^{3}\right)$. In Equation (6), DMR represents the amount of dry matter recoverable from a type of animal manure ( $\mathrm{kg} \mathrm{DM} / \mathrm{yr})$, vs. is the fraction of volatile solids in dry matter ( $\left.\mathrm{kg} \mathrm{vs.} \mathrm{kg}^{-1} \mathrm{DM}\right)$ and $Y_{\text {biogas }}$ is the biogas yield $\left(\mathrm{Nm}^{3} \mathrm{~kg}^{-1} \mathrm{VS}\right)$. In Equation (7), the $D M$ is the amount of dry matter ( $\mathrm{kg} /$ head/day), $N A$ represents the number of animals, and $F R$ is the fraction of animal manure recoverable.

$$
\begin{gathered}
E P_{\text {manure }}=A B P_{\text {manure }} \times L H V_{\text {biogas }} \\
A B P_{\text {manure }}=\Sigma\left(D M R \times v s . \times Y_{\text {biogas }}\right) \\
D M R=D M \times N A \times F R \times 365
\end{gathered}
$$

It is known that the quantity and quality of manure produced are dependent on numerous variables which include the quality and quantity of nutrition supplied to the animal, the live weight of the animal, etc. Data used in terms of manure produced per animal (kg/head/day) is shown in Table A3 in the Appendix A. It was assumed that the beef cattle produced a value of 5 , the dairy cattle 15 , chickens 0.03 , and the pigs/native swine 1.2 [49]. The data for the sheep was assumed to be the same as that of a goat, which was $1 \mathrm{~kg} /$ head/day [106].

Data used for the volatile solid/dry matter ratio (VS/DM), for all the animals, was assumed, as quoted by Bhattacharya et al. [107]. The remaining data used to calculate the $E P_{\text {manure }}$ from the cattle waste, was as quoted by Sajjakulnukit et al. [49]. For the chicken and pig calculations, all remaining data used (FA, \% DM, and the biogas yield) was from Sajjakulnukit et al. [49] and Bhattacharya et al. [107]. For the sheep and goats, the FA used was as quoted by Simonyan and Fasina [50], the DM content as per Ozcan et al. [108], and the biogas yield data from Bhattacharya et al. [107]. All the data used to calculate the $E P_{\text {manure }}$ from livestock waste is summarised in Tables A3 and A4 in the Appendix A. It is assumed that the $L H V$ of the biogas produced from both livestock and human waste is $20 \mathrm{MJ} / \mathrm{m}^{3}$, as used in various other studies for the same purpose [109-111]. It is proposed that the electricity produced from the biogas will be fed into a local mini-grid. Electrical losses do occur within mini-grids and are dependent on the size and the type of the grid, as well as the age of the equipment. Hirsch et al. [43] states that these losses can vary from 5 to $15 \%$ depending on the number of conversions between AC and DC modes. For this calculation, an average loss figure of $10 \%$ will be utilised.

\subsection{Urban Human Waste}

The energy potential from human waste was calculated based on the urban population figures for 2018 [112]. The following assumptions were used for the calculations: an average of dry matter of 0.090 (kg/head/day) [50,107], a VS/DM ratio of 0.667 , an average biogas 
yield of $0.20 \mathrm{~m}^{3} / \mathrm{kg}$ vs. [107] and a net CV of $20 \mathrm{MJ} / \mathrm{m}^{3}$. Again, electrical T \& D losses will be factored in [46], as it will be assumed that the biogas generated from towns and cities will be fed into the national grid.

\section{Results}

\subsection{Agricultural Residues}

The annual energy potential from the crops is summarised in Figure 2 and Table 5. Figure 2 shows the \% energy potential available from each crop type. This is calculated as a \% from the $E P_{\text {residue }}$ for each crop (PJ) over the sum/total $E P_{\text {residue }}$ available from all the agricultural crop residues.

Table 6 summarises the electrical generation potentials from the agricultural residue waste stream. These are expressed as Gross $G W h_{e}$ and $N e t G_{h}$ before and after $T \mathcal{E} D$ losses, at overall efficiencies of $10 \%$ and $25 \%$.

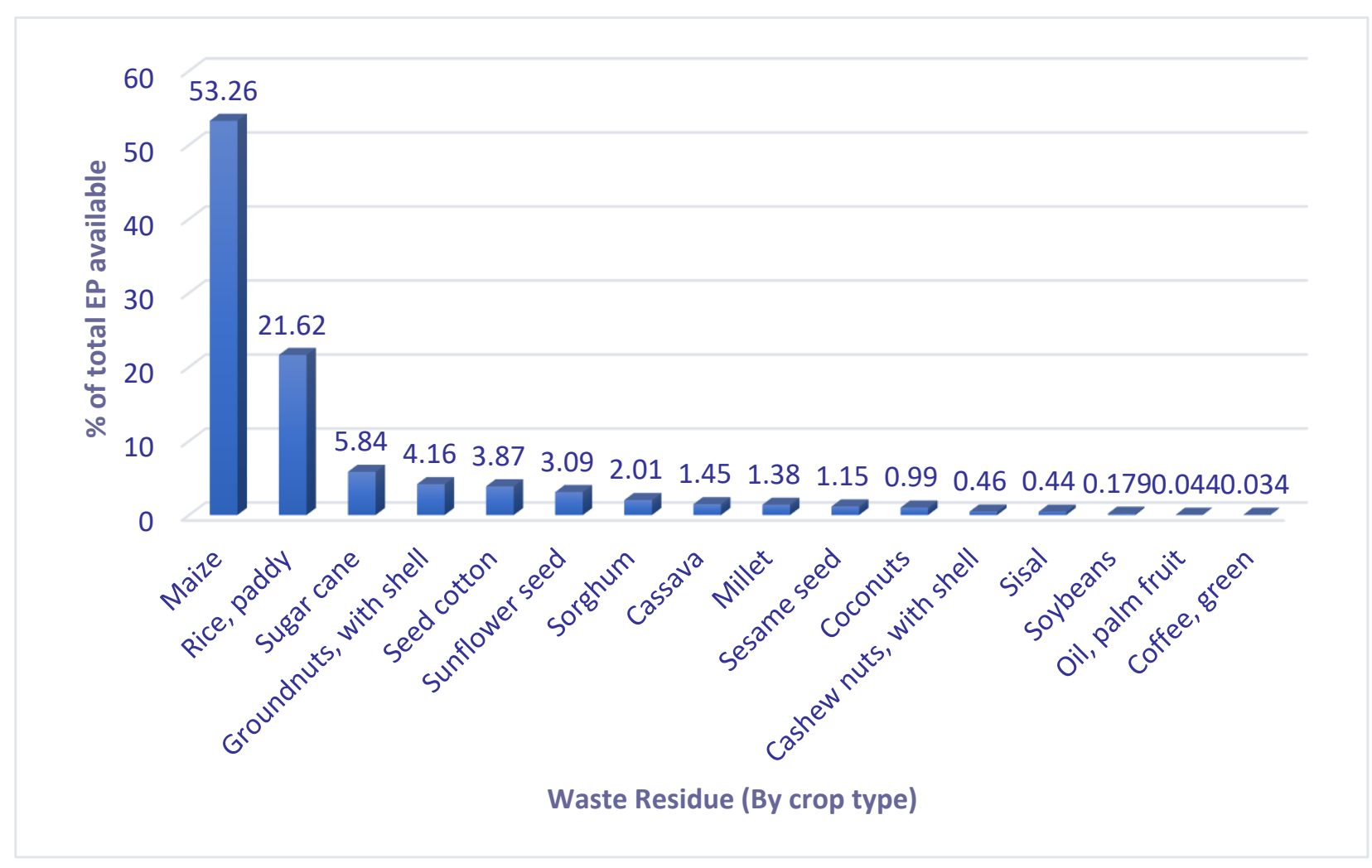

Figure 2. The \% of the total energy potential available by crop type. 
Table 5. The energy potential arising from waste agricultural residues.

\begin{tabular}{|c|c|c|c|c|c|}
\hline Crop & Amount (t) & Residue & Dry Residue (t) & $\begin{array}{c}E P_{\text {residue }} \\
\text { (PJ) }\end{array}$ & $\%$ of Total $E P_{\text {residue }}$ \\
\hline Cashew nuts, inc shell & 313,826 & Husks & $104,753.5$ & 1.56 & 0.46 \\
\hline \multirow{2}{*}{ Cassava } & $8,372,217$ & Stalks & $88,243.2$ & 1.54 & 1.45 \\
\hline & & Peelings & $313,958.1$ & 3.33 & \\
\hline \multirow[t]{2}{*}{ Coconuts } & 436,800 & Husks & $145,124.7$ & 2.70 & 0.99 \\
\hline & & Shells & $35,891.9$ & 0.65 & \\
\hline Coffee, green & 43,193 & Husks & 9178.5 & 0.114 & 0.034 \\
\hline \multirow[t]{2}{*}{ Groundnuts, inc shell } & 670,000 & Shells & $293,383.6$ & 4.59 & 4.16 \\
\hline & & Straw & $654,925.0$ & 9.43 & \\
\hline \multirow[t]{3}{*}{ Maize } & $6,273,151$ & Straw/Stalk & $7,465,049.7$ & 146.76 & 53.26 \\
\hline & & $\mathrm{Cob}$ & $1,366,658.6$ & 22.25 & \\
\hline & & Husks & $669,144.5$ & 10.41 & \\
\hline Millet & 316,194 & Straw & $376,270.9$ & 4.66 & 1.38 \\
\hline \multirow[t]{3}{*}{ Oil, palm fruit } & 75,086 & Shells & 2745.3 & 0.052 & 0.044 \\
\hline & & Fibre & 4685.4 & 0.053 & \\
\hline & & EB & 5301.8 & 0.043 & \\
\hline \multirow[t]{2}{*}{ Rice, paddy } & $3,414,815$ & Straw & $3,582,280.1$ & 57.39 & 21.62 \\
\hline & & Husks & $798,971.4$ & 15.44 & \\
\hline \multirow[t]{3}{*}{ Seed cotton } & 269,393 & Stalks & $709,870.0$ & 9.28 & 3.87 \\
\hline & & * Cake & $134,696.5$ & 2.51 & \\
\hline & & * Hull/husks & $70,042.2$ & 1.26 & \\
\hline \multirow[t]{2}{*}{ Sesame seed } & 640,000 & *Cake & 224,000 & 2.14 & 1.15 \\
\hline & & ${ }^{*}$ Hull & 96,000 & 1.75 & \\
\hline \multirow[t]{2}{*}{ Sisal } & 32,460 & Pulp & $70,113.6$ & 1.01 & 0.44 \\
\hline & & Ball/fibre & $33,417.6$ & 0.48 & \\
\hline Sorghum & 672,235 & straw & $547,115.3$ & 6.77 & 2.01 \\
\hline \multirow[t]{2}{*}{ Soybeans } & 21,321 & Straw & $34,750.6$ & 0.43 & 0.18 \\
\hline & & Pods & $13,900.2$ & 0.17 & \\
\hline \multirow[t]{2}{*}{ Sugar cane } & $3,117,812$ & Tops/leaves & $830,023.9$ & 13.12 & 5.84 \\
\hline & & Bagasse & $361,666.2$ & 6.55 & \\
\hline \multirow[t]{3}{*}{ Sunflower seed } & $1,000,000$ & * Cake & 350,000 & 5.55 & 3.09 \\
\hline & & ${ }^{*}$ Hull & 250,000 & 4.88 & \\
\hline & & TOTAL & $19,642,162.2$ & 336.9 & \\
\hline
\end{tabular}

* Residues arising from oilseed crops.

Table 6. Summary of the electrical generation potential using agricultural residues.

\begin{tabular}{cc}
\hline Data & GWh Equivalent \\
\hline Gross GWh at $100 \%$ efficiency & 93,580 \\
For an overall efficiency of $10 \%$ before any losses & 9358 \\
Net $G W h_{e}$ (for an overall efficiency of $10 \%$ ) after $T \mathcal{E} D$ losses & 7775 \\
For an overall efficiency of 25\% before any losses & 23,395 \\
Net $G W h_{e}$ (for an overall efficiency of 25\%) after TED losses & 19,438 \\
\hline
\end{tabular}

National electricity generated in 2018 = 7230 GWh [46].

\subsection{Forestry Residues}

The energy potential of the forestry residues has been calculated based on literature LHVs. In some cases where literature LHV's vary, a high and low energy potential value $\left(\mathrm{PJ}^{1}\right.$ and $\left.\mathrm{PJ}^{2}\right)$ has been calculated to reflect this variation, as shown in Tables 7 and 8 . 
Table 7. The EP available from the forestry residues in Tanzania.

\begin{tabular}{ccccccc}
\hline \multirow{2}{*}{ Type } & \multirow{2}{*}{ Residue } & \multirow{2}{*}{ \% Availability } & \multicolumn{2}{c}{ Residues } & \multicolumn{2}{c}{ Energy Potential } \\
\cline { 5 - 7 } & & & $\mathbf{m}^{\mathbf{3}}$ & OD Mass (t) & PJ $^{\mathbf{( 1 )}}$ & PJ $^{(\mathbf{2})}$ \\
\hline \multirow{2}{*}{ Logging } & Solid Wood & 40 & 646,400 & 304,454 & 5.75 & 6.30 \\
& Dust & 20 & 323,200 & 71,104 & 1.31 & 1.31 \\
\multirow{2}{*}{ Sawmilling } & Solid Wood & 38 & 614,080 & 289,232 & 5.46 & 5.98 \\
& Dust & 12 & 193,920 & 42,662 & 0.79 & 0.79 \\
\multirow{2}{*}{ Plywood } & Solid Wood & 45 & 6750 & 3179 & 0.06 & 0.06 \\
& Dust & 5 & 750 & 165 & 0.003 & 0.003 \\
\hline & Total & & $1,785,100$ & 710,797 & 13.4 & 14.4 \\
\hline
\end{tabular}

$\mathrm{PJ}^{(1)}$ and PJ ${ }^{(2)}$ calculated values reflect the different literature values of the LHV used (see Table A5 in the Appendix A).

Table 8. Summary of the electrical generation potential available from forestry residues.

\begin{tabular}{|c|c|c|}
\hline Data & $\begin{array}{l}\text { GWh Equivalent Based } \\
\text { on PJ }^{(1)}\end{array}$ & $\begin{array}{l}\text { GWh Equivalent Based } \\
\text { on PJ }\end{array}$ \\
\hline Gross (100\% efficiency) & 3715 & 4014 \\
\hline $\begin{array}{l}\text { Overall efficiency of } 10 \% \text { before } \\
\text { any losses }\end{array}$ & 372 & 401 \\
\hline $\begin{array}{c}\text { Net } G W h_{e} \text { (for an overall efficiency of } \\
10 \% \text { ) after } T \mathcal{E} D \text { losses }\end{array}$ & 309 & 334 \\
\hline $\begin{array}{l}\text { Overall efficiency of } 25 \% \text { before } \\
\text { any losses }\end{array}$ & 929 & 1004 \\
\hline $\begin{array}{c}\text { Net } G W h_{e} \text { (for an overall efficiency of } \\
25 \% \text { ) after TED losses }\end{array}$ & 772 & 834 \\
\hline
\end{tabular}

Table 8 summarises the electrical generation potentials from the forestry residues. These are expressed as Gross $G W h_{e}$ and Net $G W h_{e}$ before and after $T \mathcal{E} D$ losses, at overall efficiencies of 10 and $25 \%$.

\subsection{Livestock Residues}

The $A B P_{\text {manure }}$ and the $E P_{\text {manure }}$ were calculated from the livestock data as shown in Tables 9 and 10 and Figure 3. Figure 3 shows the \% energy potential available from each animal type. This is calculated as a \% from the $E P_{\text {manure }}$ in PJ generated from the waste of each animal over the sum/total $E P_{\text {manure }}$ available from all the livestock waste residues.

Table 9. The energy potential (EP) available from the livestock residues in Tanzania.

\begin{tabular}{|c|c|c|c|c|c|c|c|c|}
\hline $\begin{array}{l}\text { Type of } \\
\text { Animal }\end{array}$ & $\begin{array}{c}N A \\
\text { (Head) }\end{array}$ & $F A$ & $\begin{array}{l}D M \\
(\%)\end{array}$ & $\begin{array}{c}D M R(k t \\
D M / y)\end{array}$ & $V S / D M$ & $\begin{array}{l}\text { Biogas Yield } \\
\left(\mathrm{m}^{3} / \mathrm{kg} \text { VS }\right)\end{array}$ & $\begin{array}{c}A B P_{\text {Manure }} \\
\left(\mathrm{Mm}^{3} / \mathrm{y}\right)\end{array}$ & $\begin{array}{c}E P_{\text {manure }} \\
(\mathrm{PJ})\end{array}$ \\
\hline Cattle: Beef & $26,398,742$ & 0.5 & 17.44 & 4201.1 & 0.934 & 0.307 & 1204.6 & 24.09 \\
\hline Cattle: Dairy & 883,960 & 0.8 & 17.44 & 675.2 & 0.934 & 0.307 & 193.6 & 3.87 \\
\hline Chicken & $37,992,000$ & 0.8 & 33.99 & 113.1 & 0.465 & 0.18 & 9.5 & 0.19 \\
\hline Pigs/swine & 520,853 & 0.8 & 35.22 & 64.3 & 0.893 & 0.217 & 12.5 & 0.25 \\
\hline Sheep & $7,945,775$ & 0.3 & 25.0 & 217.5 & 0.912 & 0.31 & 61.5 & 1.23 \\
\hline Goat & $18,497,912$ & 0.4 & 25.0 & 675.2 & 0.598 & 0.31 & 125.2 & 2.50 \\
\hline TOTAL & & & & 5946.4 & & & 1607 & 32.1 \\
\hline
\end{tabular}


Table 10. Summary of the electrical generation potential from livestock residues.

\begin{tabular}{cc}
\hline Data & GWh Equivalent \\
\hline Gross GWhe at $100 \%$ efficiency & 8927 \\
\hline For an overall efficiency of $10 \%$ before microgrid losses & 893 \\
\hline Net $G W h_{e}$ (for an overall efficiency of $10 \%$ ) after microgrid losses & 803 \\
\hline For an overall efficiency of $25 \%$ before microgrid losses & 2232 \\
\hline Net $G W h_{e}$ (for an overall efficiency of $25 \%$ ) after microgrid losses & 2008 \\
\hline
\end{tabular}

National electricity generated in $2018=7230$ GWh [46].

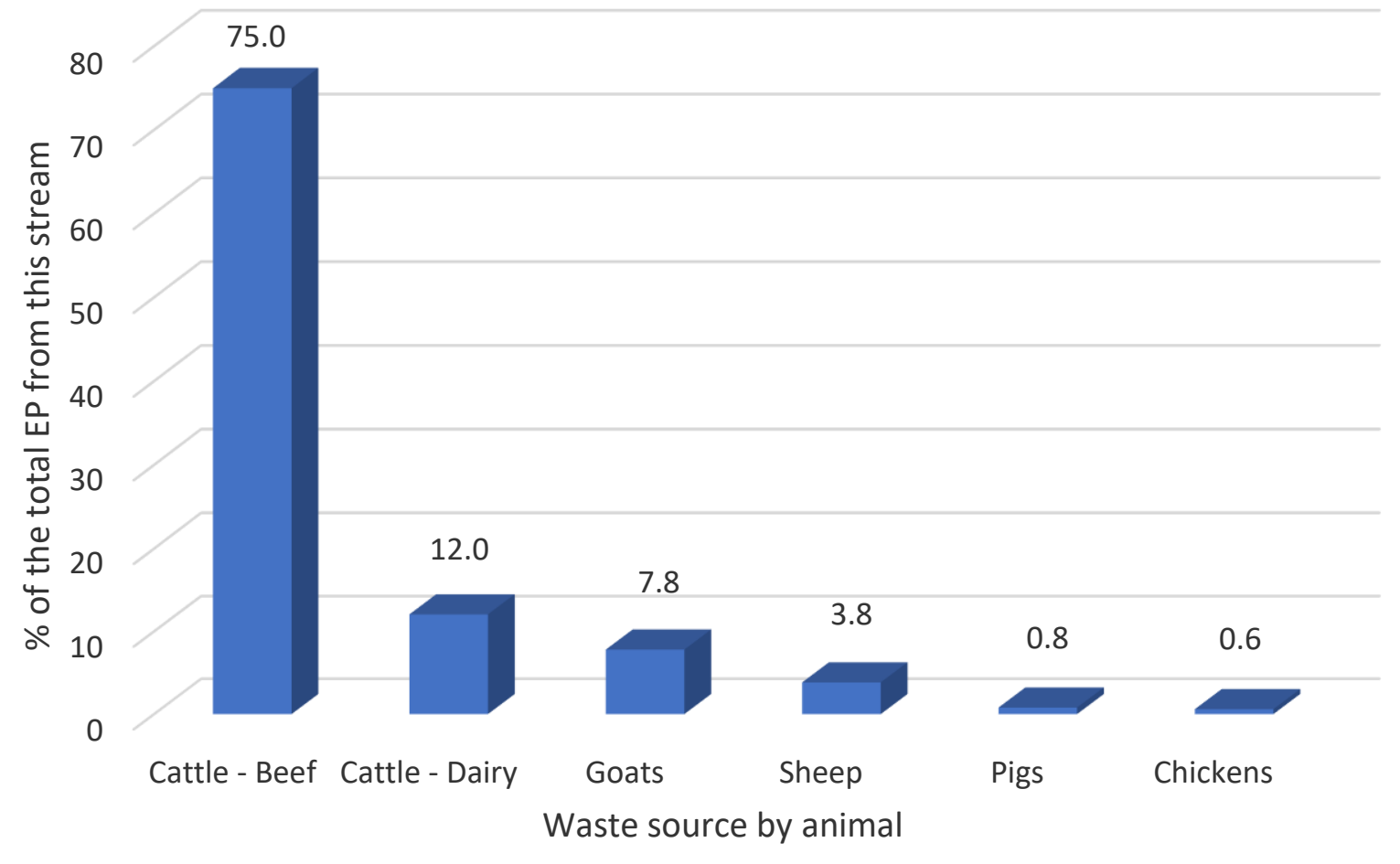

Figure 3. The total energy potential (\%) available per animal.

Table 10 summarises the electrical generation potentials from the livestock residues. These are expressed as Gross $G W h_{e}$ and Net $G W h_{e}$ before and after microgrid losses, at overall efficiencies of 10 and $25 \%$.

\subsection{Urban Human Residues}

The biogas yield and the energy potential available from the urban human waste residues are shown in Table 11.

Table 12 summarises the electrical generation potentials from the urban human waste stream. These are expressed as Gross $G W h_{e}$ and $N e t G W h_{e}$ before and after $T \mathcal{E} D$ losses, at overall efficiencies of 10 and $25 \%$. 
Table 11. The biogas potential and EP available from urban human waste in Tanzania.

\begin{tabular}{cc}
\hline Item & Value \\
\hline Urban population in 2018 [112] & $19,022,085$ \\
Average dry matter production, (kg/head/day) $[50,107]$ & 0.090 \\
Total dry matter/year, (tonnes) & $624,875.5$ \\
Total Biogas produced $\left(\mathrm{M} \mathrm{m}^{3}\right.$ in 2018$)$ & 83.4 \\
LHV of biogas $\left(\mathrm{MJ} / \mathrm{m}^{3}\right.$ ) & 20 \\
Biogas yield, (Biogas $\mathrm{m}^{3} / \mathrm{kg} \mathrm{VS}^{\text {V }}[107]$ & 0.20 \\
Total EP (PJ) in 2018 & 1.67 \\
\hline
\end{tabular}

Table 12. Summary of the electrical generation potential from urban human waste.

\begin{tabular}{cc}
\hline Data & GWh Equivalent \\
\hline Gross-at $100 \%$ efficiency & 463 \\
\hline For an overall efficiency of $10 \%$ before any losses & 46 \\
\hline Net $G W h_{e}$ (for an overall efficiency of $10 \%$ ) after TED losses & 38 \\
\hline For an overall efficiency of $25 \%$ before any losses & 116 \\
\hline Net $G W h_{e}$ (for an overall efficiency of $25 \%$ ) after TED losses & 96 \\
\hline National electricity generated in 2018 = 7230 GWh [46].
\end{tabular}

\section{Discussion}

\subsection{Agricultural Residues}

The total solid biomass residue from this stream produced in 2018 equates to approximately $19,642 \mathrm{kt}$, which had a total calculated energy potential of $337 \mathrm{PJ}$. The residues from this stream can produce between 7775 and 19,438 GWh of electricity after incorporating $\mathrm{T} \& \mathrm{D}$ losses. A range is quoted as this is based on overall efficiencies of 10 and $25 \%$. This stream is theoretically capable of generating 1.1 to 2.7 times equivalent of the annual electricity produced in 2018. This is reflective of the large agricultural sector present in this country. Some of these waste residues have alternate uses, including use in energy cogeneration from the sugar and sisal production [55]. However, overall a large amount remains underutilised [18,55]. It is recognised that in Tanzania, the potential for utilising such residues to produce more sustainable power/electricity generation is high but underexploited [12]. Furthermore, low grass productivity combined with high fertiliser costs produce challenging conditions for farmers in this country, hence using crop residues for farming purposes such as fodder or fertiliser remains a priority for many farmers [55]. Hence, the decision to utilise waste agricultural residues for producing small-scale electricity versus the competing uses has to be considered locally, on a case by case basis with careful consideration based on the type of crop residue.

Due to the high volumes of agricultural residues available, theoretically, these residues could be utilised for large-scale energy generation; however, there are issues associated with the cost of transportation from the agricultural centres to the large power generation plants. The cost issues lie with the low bulk density residues of these residues. Furthermore, the availability of these crop residues is seasonal; hence there will be periods when the supply is intermittent. Utilising these residues locally as an energy source for small- scale energy generation avoids these issues mentioned. For the small-scale applications, as considered in this paper, it is feasible to utilise/store these residues in bulk near the point of consumption. Ideally, such residues should be stored close to the gasification unit coupled with an ICE/diesel generator (which is linked to either the national grid or a mini-grid).

\subsection{Forestry Residues}

The mean energy potential of these forestry residues is calculated at $13.9 \mathrm{PJ}$. The residues from this stream can produce on average between 322 and 803 GWh of electricity after incorporating T \& D losses, as it is assumed this energy will be fed into the 
national/mini-grid. The energy potential from this stream is relatively small; it is only capable of generating at best, $11 \%$ of the annual electricity produced in 2018.

\subsection{Livestock Residues}

This data shows that there is significant energy potential from the collection of animal manure to produce biogas, equivalent to $32.1 \mathrm{PJ}$. The residues from this stream can produce between 803 to $2008 \mathrm{GWh}$ of electricity, after incorporating microgrid T \& D losses. A range is quoted as this has been calculated on overall efficiencies of 10 and $25 \%$. This is equivalent to generating approximately 11 to $28 \%$ of the annual electricity produced in 2018 . The utilisation of this technology is highly feasible in this country when utilising this waste stream as most of the livestock/animals are concentrated in certain regions of the country in the arid/semi-arid regions. For example, a study by Mwakaje, [113] in southwest Tanzania revealed that there is potential to develop biogas technology in this region due to its high population density (high demand) with a large number of indoor-fed cattle and/or pigs. The constraints identified by Mwkaje [113] were cost/affordability and water scarcity, to a lesser degree, lack of technical support. Again, Rupf et al. [17] echoed this by reiterating that various factors need consideration for the usage of biodigesters in Africa. These include feedstock availability, water supply, energy demand, local materials and labour, and the level of commitment to operate and maintain the biodigester effectively. Other factors that may affect uptake are the local culture and the location [114]. Roopnarain [27] identified further barriers as cost implications, lack of communication, lack of ownership, and the negative image of the technology caused by past failures.

In addition, the livestock numbers may vary from household to household and over an annual period [114]. The benefits of establishing communal biogas digesters include the reduction or shared cost within householders, as well as providing a more continuous feedstock [114]. The biogas produced could be piped/distributed within small communities to produce electricity using dual fuel engines. Existing diesel/spark gen set engines can be converted to run on dual fuel mode to utilise this biogas.

\subsection{Urban Human Waste Residues}

Tanzania has a biomass energy potential that can be generating by processing urban human waste using $\mathrm{AD}$ which can be estimated as $1.67 \mathrm{PJ}$ of energy. The residues from this stream can produce between 38 and 96 GWh of electricity depending on the overall efficiency of the processes/conversions involved after incorporating mini-grid losses. The energy potential from this stream is very small due to the low level of urbanisation in 2018 whereby approximately $66.2 \%$ of the total Tanzanian population lived in rural regions [4]. Hence this waste stream can generate at best, only $1 \%$ of the annual electricity produced in 2018 (after accounting for T \& D losses).

\subsection{The Combined Energy Potential of All Four Waste Streams}

Figure 4 shows the raw EP of each waste stream. Approximately $87.6 \%$ of all the raw EP arises solely from agricultural residues. Table 13 shows that when all the residues are combined for 2018, Tanzania has a huge net energy-generating potential. The net electricity generation potential accounts for the overall efficiency of the technologies, and any transmission/distribution losses which may occur due to the national or a microgrid. Calculations show that the net electricity generation potential from these combined residues is equivalent to generating approximately 1.2 to 3.1 times of the total electrical energy generated in 2018. However, one should take into consideration that these residues have seasonal availability hence to ensure a continuous supply, the usage of the residues will require some management. 


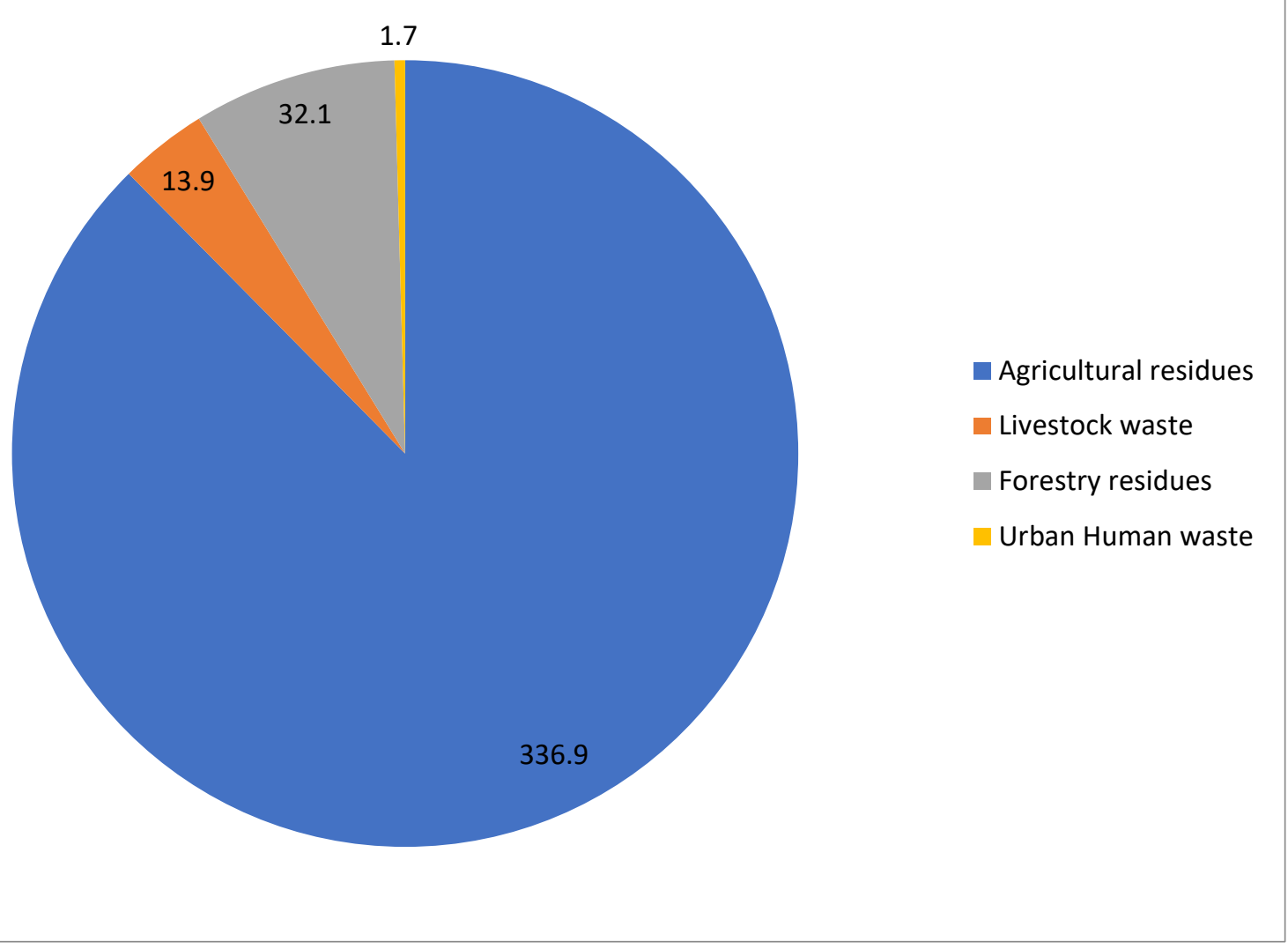

Figure 4. A comparison of the raw energy potential (PJ) of each waste stream.

Table 13. A summary of the biomass assessment results for Tanzania.

\begin{tabular}{|c|c|c|c|c|c|}
\hline \multirow[b]{2}{*}{ Residue: } & \multirow[b]{2}{*}{$\begin{array}{c}\text { Gross } \mathrm{GWh}_{\mathrm{e}} \\
\text { at } 100 \% \\
\text { Efficiency }\end{array}$} & \multicolumn{4}{|c|}{$\mathrm{GWh}_{\mathrm{e}}$ for Overall Efficiencies of: } \\
\hline & & $\begin{array}{c}10 \% \text { before } \\
\text { Losses }\end{array}$ & $\begin{array}{c}25 \% \text { before } \\
\text { Losses }\end{array}$ & $\begin{array}{c}10 \% \text { after } \\
\text { Losses }\end{array}$ & $\begin{array}{c}25 \% \text { after } \\
\text { Losses }\end{array}$ \\
\hline Agricultural & 93,580 & 9358 & 23,395 & 7775 & 19,438 \\
\hline Forestry & *3865 & * 387 & $* 966$ & * 322 & $* 803$ \\
\hline Livestock & 8927 & 893 & 2232 & 803 & 2008 \\
\hline Urban Human & 463 & 46 & 116 & 38 & 96 \\
\hline TOTAL & 106,835 & 10,684 & 26,709 & 8938 & 22,345 \\
\hline $\begin{array}{l}\% \text { of the electricity } \\
\text { generation capacity } \\
\text { possible (2018) }\end{array}$ & 1478 & 148 & 369 & 124 & 309 \\
\hline
\end{tabular}

Utilising AD for livestock and urban human waste slurries is technically feasible; however, there are many barriers to overcome to make this a reality in many rural locations. The barriers include the large, fixed capital costs required for set up, and lack of technical expertise $[16,27]$. Governmental subsidies and interventions are required to provide training, and this needs to be promoted by favourable governmental policies. This technology becomes more feasible in a centralised village location scenario, whereby the costs and feedstocks can be shared. This also enables a more continuous supply of biogas to be generated which can be transported via a network to a larger number of users. 


\section{Conclusions}

The agricultural waste residues have the highest estimated energy potential followed by the livestock residues. The energy potential from the other two waste streams is much smaller due to a small forestry/logging industry combined with a low urban population. However, overall, combined these residues have a huge energy potential of 385 PJ which is generated from approximately 26,924 kilotonnes of dry waste. This study shows that renewable and sustainable energy can be generated from these residues as the net electricity generation potential from these combined residues (after accounting for T \& D losses) is equal to approximately 1.2 to 3.1 times of the total electrical energy generated nationally in 2018. This can in turn lead to a reduction in the usage and dependency on fossil fuels, whilst making access to electricity more affordable. However, it is more economical and practical to utilise these residues on a village scale using small gasifiers near the point of production/storage. This entails the residues being stored near the gasification unit coupled with an ICE/diesel generator (linked to either the national grid or a mini-grid). The gas produced can be fed into the air intake of an existing ICE used to produce smallscale electricity.

Utilising these waste residues offers further advantages which benefit the environment as the usual disposal/waste management techniques associated with these waste streams are avoided. To utilise these waste streams using the technologies discussed in this paper, it is very important to match supply with demand whilst considering the seasonal and regional availability of the feedstock. Further work is required to determine which communities would benefit from which technology based on the local availability/supply logistics of these waste residue streams, any competing uses, the population density, and any government incentives which can influence the uptake in this region.

Author Contributions: Conceptualization, Z.A. and H.L.; methodology, Z.A.; validation, Z.A.; investigation, Z.A.; writing—original draft preparation, Z.A.; writing—review and editing, Z.A., J.C.L., J.H., and H.L.; visualization, Z.A., supervision, H.L., G.A., and A.R.; project administration, Z.A. and H.L. All authors have read and agreed to the published version of the manuscript.

Funding: This research was possible due to the financial aid by The Engineering and Physical Sciences Research Council (EPSRC) for a PhD studentship for Zahida Aslam in the Centre for Doctoral Training in Bioenergy (EP/L014912/1), and a GCRF grant: Creating resilient sustainable micro-grids through hybrid renewable energy systems (CRESUM-HYRES), grant number EP/R030243/1.

Institutional Review Board Statement: Not applicable.

Informed Consent Statement: Not Applicable.

Data Availability Statement: Data is contained within the article. The data presented in this study are available in 'Increasing Access to Electricity: An Assessment of the Energy and Power Generation Potential from Biomass Waste Residues in Tanzania'.

Conflicts of Interest: The authors declare no conflict of interest.

\section{Nomenclature \& Abbreviations}

$A B P_{\text {manure }}$ Amount of biogas from recoverable manure $\left(\mathrm{Nm}^{3} \mathrm{yr}^{-1}\right)$

AC Alternating current

AD Anaerobic digestion

AH Annual harvest of the crop or product ( $\mathrm{t}$ )

$A R G \quad$ Amount of a residue generated annually $\left(\mathrm{t} \mathrm{yr}^{-1}\right)$

$\mathrm{CO}_{2} \quad$ Carbon dioxide

$\mathrm{CV} \quad$ Calorific value

daf Dry ash free

DC Direct current 


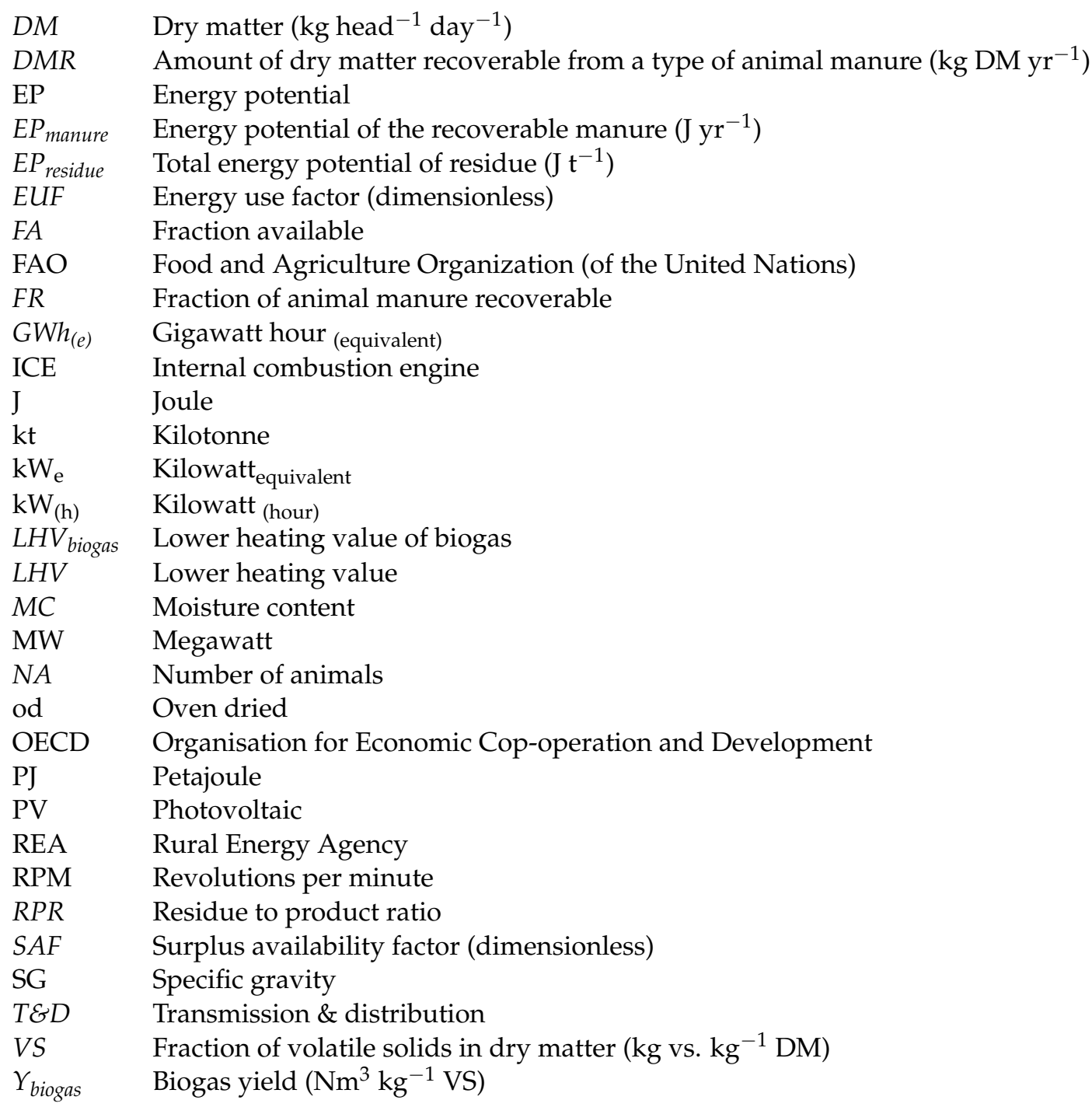

\section{Appendix A}

Table A1. Raw data of the softwood tree species for the basic density calculation.

\begin{tabular}{|c|c|c|}
\hline Species Name (Common/Scientific) & OD wt/Green Volume $\left(\mathrm{g} / \mathrm{cm}^{3}\right)$ & Source(s) \\
\hline Slash Pine/Pinus elliottii & 0.54 & [78] \\
\hline Caribbean Pine/Pinus caribaea & 0.51 & [80] \\
\hline Patula Pine/Pinus patula & 0.45 & [81] \\
\hline Khasi Pine/Pinus kesiya & 0.45 & [82] \\
\hline Radiata Pine/Pinus radiata & 0.41 & [83] \\
\hline African Juniper/Juniperus procera & 0.44 & [84] \\
\hline Mexican Cypress/Cupressus lusitanica & 0.40 & [85] \\
\hline Average SG & 0.457 & \\
\hline
\end{tabular}


Table A2. Raw data of the hardwood tree species for the basic density calculation.

\begin{tabular}{|c|c|c|}
\hline Species Name (Common/Scientific) & OD wt/Green Volume $\left(\mathrm{g} / \mathrm{cm}^{3}\right)$ & Source(s) \\
\hline Black Wattle/Acacia mearnsii & 0.59 & [86] \\
\hline $\begin{array}{l}\text { Australian Blackwood/Acacia } \\
\text { melanoxylon }\end{array}$ & 0.54 & [87] \\
\hline Sheaok/Casuarina spp & 0.62 & [97] \\
\hline Spanish Cedar/Cedrela odorata & 0.38 & [88] \\
\hline Camphor/Cinnamomum camphora & 0.43 & [89] \\
\hline Iroko/Chlorophora regia & 0.55 & [79] \\
\hline River Red Gum/Eucalyptus camaldulensis & 0.67 & [90] \\
\hline Blue Gum/Eucalyptus maidenii & 0.68 & [91] \\
\hline Rose Gum/Eucalyptus grandis & 0.48 & [92] \\
\hline Southern Silky Oak/Grevillea robusta & 0.49 & [93] \\
\hline Olive/Olea capensis & 0.72 & [94] \\
\hline Idigbo/Terminalia ivorensis) & 0.43 & [95] \\
\hline Teak/Tectona grandis & 0.55 & [96] \\
\hline Average SG & 0.548 & \\
\hline
\end{tabular}

Table A3. Data sources for the fresh waste calculation of animal waste.

\begin{tabular}{ccc}
\hline Animal & Fresh Waste (kg/Head/Day) & Source \\
\hline Cattle-Beef & 5 & {$[49]$} \\
Cattle-Dairy & 15 & {$[49]$} \\
Chicken & 0.03 & {$[49]$} \\
Pigs ${ }^{1}$ & 1.2 & {$[49]$} \\
Sheep & 1 & {$[106]$} \\
Goat & 1 & {$[106]$} \\
\hline
\end{tabular}

${ }^{1}$ Data based on a native swine.

Table A4. Source(s) and data used for the calculation of the EP from livestock waste.

\begin{tabular}{ccccc}
\hline Animal & $\boldsymbol{F A}$ & $\mathbf{( \% )} \mathbf{D M}$ & VS/DM Ratio & Biogas Yield $\left(\mathbf{m}^{\mathbf{3}} / \mathbf{k g}\right.$ VS) \\
\hline Cattle-Beef & $0.5[49]$ & $17.44[49]$ & $0.934[107]$ & $0.307[49]$ \\
Cattle-Dairy & $0.8[49]$ & $17.44[49]$ & $0.934[107]$ & $0.307[49]$ \\
Chicken & $0.8[49]$ & $33.99[49]$ & $0.465[107]$ & $0.18[107]$ \\
Pigs & $0.8[49]$ & $35.22[49]$ & $0.893[107]$ & $0.217[49]$ \\
Sheep & $0.3[50]$ & $25[108]$ & $0.912[107]$ & $0.31[107]$ \\
Goat & $0.4[50]$ & $25[108]$ & $0.598[107]$ & $0.31[107]$ \\
\hline
\end{tabular}

Table A5. Source(s) and data used for the calculation of the forestry residues.

\begin{tabular}{cccc}
\hline Type & Residue & LHV Data Source & LHV Daf (MJ/kg) \\
\hline Logging and Sawmilling & Solid Wood & {$[101,102]$} & 18.8920 .69 \\
Logging, Sawmilling, and & Dust & {$[100]$} & 18.46 \\
Plywood & Solid Wood & {$[99,103]$} & 18.0620 .34 \\
\hline Plywood & . & & \\
\hline
\end{tabular}

\section{References}

1. United Nations. Goal 7: Ensure Access to Affordable, Reliable, Sustainable and Modern Energy for All. 2016. Available online: https://unstats.un.org/sdgs/report/2016/goal-07/ (accessed on 16 November 2020).

2. IBRD-IDA. Population, Total 2021a, The World Bank Group-DataBank. Available online: https://data.worldbank.org/indicator/ SP.POP.TOTL?locations=TZ (accessed on 17 November 2020).

3. IBRD-IDA. \% of the Population with Access to Electricity, Total in Tanzania. The World Bank Group-DataBank. 2021. Available online: https:/ / data.worldbank.org/indicator/EG.ELC.ACCS.ZS?locations=TZ (accessed on 17 November 2020).

4. IBRD-IDA. Rural population (\% of Total Population) in Tanzania. The World Bank Group—DataBank. 2021. Available online: https: / / data.Worldbank.org/indicator/SP.RUR.TOTL.ZS?locations=TZ (accessed on 17 November 2020). 
5. IBRD-IDA. Access to Electricity, Rural (\% of Rural Population) in Tanzania. The World Bank Group. 2021. Available online: https:/ / data.worldbank.org/indicator/EG.ELC.ACCS.RU.ZS?locations=TZ (accessed on 17 November 2020).

6. IEA. Africa Energy Outlook 2019. Overview: Tanzania. World Energy Outlook Special Report. 2019. Available online: www.iea.org/ reports/africa-energy-outlook-2019 (accessed on 14 February 2021).

7. Ahlborg, H.; Hammar, L. Drivers and barriers to rural electrification in Tanzania and Mozambique-Grid-extension, off-grid, and renewable energy technologies. Renew. Energy 2014, 61, 117-124. [CrossRef]

8. Bertheau, P.; Cader, C.; Müller, H.; Blechinger, P.; Seguin, R.; Breyer, C. Energy Storage Potential for Solar Based Hybridization of Off-grid Diesel Power Plants in Tanzania. Energy Procedia 2014, 46, 287-293. [CrossRef]

9. The United Republic of Tanzania. Tanzania's SE4ALL Action Agenda; UNDP, Ed.; Ministry of Energy and Minerals: Dar es Salaam, Tanzania, 2015.

10. Moner-Girona, M.; Ghanadan, R.; Solano-Peralta, M.; Kougias, I.; Bódis, K.; Huld, T.; Szabó, S. Adaptation of Feed-in Tariff for remote mini-grids: Tanzania as an illustrative case. Renew. Sustain. Energy Rev. 2016, 53, 306-318. [CrossRef]

11. Teske, S.; Morris, T.; Kriti, N. 100\% Renewable Energy for Tanzania-Access to Renewable and Affordable Energy for All within One Generation. Report Prepared by ISF for Bread for the World. October 2017. Available online: https://www. worldfuturecouncil.org/wp-content/uploads/2017/11/Tanzania-Report-8_Oct-2017-BfdW_FINAL.pdf (accessed on 14 February 2021).

12. African Development Group. Renewable Energy in Africa: TANZANIA Country Profile; Immeuble du Centre de Commerce International d'Abidjan-CCIA: Abidjan, Côte d'Ivoire, 2015.

13. Felix, M.; Gheewala, S.H. A Review of Biomass Energy Dependency in Tanzania. Energy Procedia 2011, 9, 338-343. [CrossRef]

14. Titcombe, M.; Simcik, M. Personal and indoor exposure to $\mathrm{PM}_{2.5}$ and polycyclic aromatic hydrocarbons in the southern highlands of Tanzania: A pilot-scale study. Environ. Monit. Assess. 2011, 180, 461-476. [CrossRef] [PubMed]

15. Aberilla, M.J.; Gallego-Schmid, A.; Azapagic, A. Environmental sustain ability of small-scale biomass power technologies for agricultural communities in developing countries. Renew. Energy 2019, 141, 493-506. [CrossRef]

16. Kemausuor, F.; Adaramola, M.S.; Morken, S. A Review of Commercial Biogas Systems and Lessons for Africa. Energies 2018, 11, 2984. [CrossRef]

17. Rupf, G.V.; Bahri, P.A.; de Boer, K.; McHenry, M.P. Broadening the potential of biogas in Sub-Saharan Africa: An assessment of feasible technologies and feedstocks. Renew. Sustain. Energy Rev. 2016, 61, 556-571. [CrossRef]

18. Kusekwa, M.A. Biomass Conversion to Energy in Tanzania: A Critique. In New Developments in Renewable Energy [online]; Arman, H., Yuksel, I., Eds.; InTechOpen: London, UK, 2013; Available online: https://www.intechopen.com/books/newdevelopments-in-renewable-energy / biomass-conversion-to-energy-in-tanzania-a-critique (accessed on 14 February 2021).

19. Ferronato, N.; Torretta, V. Waste Mismanagement in Developing Countries: A Review of Global Issues. Int. J. Environ. Res. Public Health 2019, 16, 1060. [CrossRef]

20. Lebuhn, M.; Munk, B.; Effenberger, M. Agricultural biogas production in Germany—From practice to microbiology basics. Energy Sustain. Soc. 2014, 4, 1-21. [CrossRef]

21. FAO. Burning-Crop Residues. Food and Agricultural Organisation of the United Nations. 2021. Available online: http: //www.fao.org/faostat/en/\#data/GB (accessed on 17 February 2021).

22. Clauser, N.M.; González, G.; Mendieta, C.M.; Kruyeniski, J.; Area, M.C.; Vallejos, M.E. Biomass Waste as Sustainable Raw Material for Energy and Fuels. Sustainability 2021, 13, 794. [CrossRef]

23. Laramee, J.; Davis, J. Economic and environmental impacts of domestic bio-digesters: Evidence from Arusha, Tanzania. Energy Sustain. Dev. 2013, 17, 296-304. [CrossRef]

24. Gebreegziabher, Z.; Naik, L.; Melamu, R.; Balana, B.B. Prospects and challenges for urban application of biogas installations in Sub-Saharan Africa. Biomass Bioenergy 2014, 70, 130-140. [CrossRef]

25. Chaves, L.I.; DaSilva, M.J.; Melegari de Souza, S.N.; Secco, D.; Rosa, H.A.; Nogueria, C.E.C.; Frigo, E.P. Small-scale power generation analysis: Downdraft gasifier coupled to engine generator set. Renew. Sustain. Energy Rev. 2016, 58, 491-498. [CrossRef]

26. LTS International Limited, T.U.o. Edinburgh, and E4tech. Bioenergy for Sustainable Energy Access in Africa. In Project Completion and Handover Report; Penicuik: Scotland, UK, 2017.

27. Roopnarain, A.; Adeleke, R. Current status, hurdles and future prospects of biogas digestion technology in Africa. Renew. Sustain. Energy Rev. 2017, 67, 1162-1179. [CrossRef]

28. Park, C.S.; Roy, P.S.; Kim, S.H. Current Developments in Thermochemical Conversion of Biomass to Fuels and Chemicals, Gasification for Low-Grade Feedstock. In Gasification-for-Low-Grade-Feedstock [online]; Yun, Y., Ed.; InTechOpen: London, UK, 2018; Available online: https:/ /www.intechopen.com/books/gasification-for-low-grade-feedstock/current-developments-inthermochemical-conversion-of-biomass-to-fuels-and-chemicals (accessed on 17 November 2020). [CrossRef]

29. Bhattacharyya, S.C. Viability of off-grid electricity supply using rice husk: A case study from South Asia. Biomass Bioenergy 2014, 68, 44-54. [CrossRef]

30. Lyakurwa, F.S. Assessment of the energy potential of crop residues and animal wastes in Tanzania. Indep. J. Manag. Prod. 2016, 7, 1227-1239. [CrossRef]

31. Terrapon-Pfaff, J.C. Linking Energy- and Land-Use Systems: Energy Potentials and Environmental Risks of Using Agricultural Residues in Tanzania. Sustainability 2012, 4, 278-293. [CrossRef] 
32. Overend, R. Village Power '98 Scaling Up Electricity Access for Sustainable Rural Development. In Status of Biomass Gasifier Village Systems in Village Power '98; World Bank Headquarters, National Renewable Energy Laboratory: Washington, DC, USA, 1988.

33. Dasappa, S. Potential of biomass energy for electricity generation in sub-Saharan Africa. Energy Sustain. Dev. 2011, 15, 203-213. [CrossRef]

34. Martínez, J.D.; Mahkamov, K.; Andrade, R.V.; Silva Lora, E.E. Syngas production in downdraft biomass gasifiers and its application using internal combustion engines. Renew. Energy 2012, 38, 1-9. [CrossRef]

35. Tinaut, F.V.; Melgar, A.; Horrillo, A.; Díez de la Rosa, A. Method for predicting the performance of an internal combustion engine fuelled by producer gas and other low heating value gases. Fuel Process. Technol. 2006, 87, 135-142. [CrossRef]

36. Garcia-Bacaicoa, P.; Bilbao, R.; Arauzo, R.; Luisa Salvadoret, M. Scale-up of downdraft moving bed gasifiers (25-300 kg/h)Design, experimental aspects and results. Bioresour. Technol. 1994, 48, 229-235. [CrossRef]

37. Dogru, M.; Howarth, C.R.; Akay, G.; Keskinler, B.; Malike, A.A. Gasification of hazelnut shells in a downdraft gasifier. Energy 2002, 27, 415-427. [CrossRef]

38. Kirubakaran, V.; Sivaramakrishnan, V.; Nalini, R.; Sekar, T.; Premalatha, M.; Subramanian, P. A review on gasification of biomass. Renew. Sustain. Energy Rev. 2009, 13, 179-186. [CrossRef]

39. Tippayawong, N.; Promwungkwa, P.; Rerkkriangkrai, P. Long-term operation of a small biogas/diesel dual-fuel engine for on-farm electricity generation. Biosyst. Eng. 2007, 98, 26-32. [CrossRef]

40. Dasappa, S.; Subbukrishna, D.N.; Suresh, K.C.; Paul, P.J.; Prabhu, G.S. Operational experience on a grid connected 100 kWe biomass gasification power plant in Karnataka, India. Energy Sustain. Dev. 2011, 15, 231-239. [CrossRef]

41. Dasappa, S.; Sridhar, H.V.; Rajan, N.K.S.; Paul, P.J.; Upasani, A. Producer gas engines—Proponent of clean energy technology. In Proceedings of the 15th European Biomass Conference and Exhibition, Berlin, Germany, 7-11 May 2007.

42. Dasappa, S.; Sridhar, S.H. Performance of a diesel engine in a dual fuel mode using producer gas for electricity power generation. Int. J. Sustain. Energy 2013, 32, 153-168. [CrossRef]

43. Hirsch, A.; Yael, P.; Josep, G. Microgrids: A review of technologies, key drivers, and outstanding issues. Renew. Sustain. Energy Rev. 2018, 90, 402-411. [CrossRef]

44. Eisentraut, A. Sustainable Production of Second-Generation Biofuels: Potential and Perspectives in Major Economies and Developing Countries; IEA Energy Papers, No. 2010/01; OECD Publishing: Paris, France, 2010.

45. FAO. FAOSTAT Official Crops Processed Data. Food \& Agriculture Organisation of the United Nations (FAOSTAT). 2021. Available online: http:/ / www.fao.org/faostat/en/\#data/QC (accessed on 19 January 2021).

46. IEA. IEA-Statistics Search Tanzania, United Republic of Tanzania, United Republic IEA Atlas of Energy 2021. Total Electricity Generation in TWh by Country. Available online: https:/ / www.iea.org/data-and-statistics / data-tables?country=TANZANIA\& energy=Electricity\&year $=2018$ (accessed on 19 January 2021).

47. Bhattacharya, S.C.; Pham, H.L.; Shrestha, R.M.; Vu, Q.V. $\mathrm{CO}_{2}$ Emissions due to Fossil and Traditional Fuels, Residues and Wastes in Asia. In Proceedings of the AIT Workshop on Global Warming Issues in Asia, Bangkok, Thailand, 1-3 July 1993; AIT: Bangkok, Thailand, 1993.

48. Koopmans, A.; Koppejan, J. Agricultural and Forest Residues-Generation, Utilization and Availability. In Proceedings of the Regional Consultation on Modern Applications of Biomass Energy, Kuala Lumpur, Malaysia, 6-10 January 1997.

49. Sajjakulnukit, B.; Yinguad, R.; Maneekhao, V.; Pongnarintasut, V.; Bhattacharya, S.C.; Abdul Salam, P. Assessment of sustainable energy potential of non-plantation biomass resources in Thailand. Biomass Bioenergy 2005, 29, 214-224. [CrossRef]

50. Simonyan, K.J.; Fasina, O. Biomass resources and bioenergy potentials in Nigeria. Afr. J. Agric. Res. 2013, 8, 4975-4989.

51. Philippine Coconut Authority (PCA). Technical Data Handbook on the Coconutts Products and by-Products; Philippine Coconut Authority: Diliman, Quezon City, Philippines, 1979.

52. Ma, A.N.; Ong, A.S.H. Biomass Energy from the Palm Oil Industry. In Proceedings of the ASEAN Conference on Energy from Biomass, Penang, Malaysia, 13-15 October 1986.

53. Lim, K.O. The energy potential and current utilization of agriculture and logging wastes in Malaysia. Renew. Energy Rev. 1986, 8, 57-75.

54. Kabissa, J.C.B. Cotton and Its by-Products in the United Republic of Tanzania; UNCTAD: Geneva, Switzerland, 2016.

55. Terrapon-Pfaff, J.C.; Fischedick, M.; Monheim, H. Energy potentials and sustainability-The case of sisal residues in Tanzania. Energy Sustain. Dev. 2012, 16, 312-319. [CrossRef]

56. Jekayinfa, S.O.; Scholz, V. Potential Availability of Energetically Usable Crop Residues in Nigeria. Energy Sources Part A Recovery Util. Environ. Effects 2009, 31, 687-697. [CrossRef]

57. AIT-EEC. Evaluation and Selection of Lingo-Cellulose Wastes Which Can Be Converted into Substitute Fuels; AIT-EEC: Brussels, Belgium, 1983.

58. Vimal, O.P.; Tyagi, P.D. Energy from Biomass—An Indian Experience; Agricole Publishing Academy: New Delhi, India, 1984.

59. Ryan, P.; Openshaw, K. Assessment of Biomass Energy Resources: A Discussion on Its Needs and Methodology; Energy Series Paper 48; Industry and Energy Department: Washington, DC, USA, 1991.

60. Vimal, O.P. Residue utilization, management of agricultural and agro industrial residues of selected tropical crops (Indian experience). In Proceedings of the UNEP/ESCAP/FAO Workshop on Agricultural and Agro Industrial Residue Utilization in Asia and Pacific Region, Pattaya, Thailand, 10-14 December 1979; UNEP: Moscaow, Russia, 1984. 
61. U.S. Agency for International Development. Baling Sugarcane Tops and Leaves: The Thai Experience; Prepared by Winrock International, Report No. 91-15. Document No PN-ABI-900; Office of Energy and Infrastructure: Arlington, VA, USA, 1989.

62. Şahin, S.; Elhussein, E.A.A. Assessment of sesame (Sesamum indicum L.) cake as a source of high-added value substances: From waste to health. Phytochem. Rev. 2018, 17, 691-700. [CrossRef]

63. Yasothai, R. Processing method and composition of sesame oil cake-A review. Int. J. Sci. Environ. Technol. 2014, 3, $993-996$.

64. Yasothai, R. Energy content and protein quality of sesame oil cake-A review. Int. J. Sci. Environ. Technol. 2014, 3, 901-904.

65. Pathak, N.K.; Kamra, D.N. A Text Book of Livestock Feeding in Tropics; A Falcon Book from Cosmo Publications; Cosmo Publications: New Delhi, India, 1989; pp. 246-257.

66. Mehta, B.V. Sea Millennium Handbook 2000; The Solvent Extractors Association of India: Mumbai, India, $1989 ;$ Volume 7.

67. Swick, R. Considerations in using protein meals for poultry. Poult. Fortune 2001, 2, 30-38.

68. Ozyuguran, A.; Akturk, A.; Yaman, S. Optimal use of condensed parameters of ultimate analysis to predict the calorific value of biomass. Fuel 2018, 214, 640-646. [CrossRef]

69. Heuzé, V.; Tran, G.; Hassoun, P.; Bastianelli, D.; Lebas, F. Cottonseed Meal. 2020, Feedipedia, a Programme by INRA, CIRAD, AFZ and FAO. Available online: https:/ / www.feedipedia.org/node/550 (accessed on 5 January 2021)

70. Magasiner, N.; de Kock, J.W. Design criteria for fibrous fuel fired boilers. Energy World 1987, 8-9, 4-12.

71. ECN. Phyllis2, Database for (Treated) Biomass, Algae, Feedstocks for Biogas Production and Biochar. ECN.TNO. 2021. Available online: https:/ / phyllis.nl/Biomass/View/370 (accessed on 5 January 2021).

72. Gerçel, H.F. The production and evaluation of bio-oils from the pyrolysis of sunflower-oil cake. Biomass Bioenergy 2002, 23, 307-314. [CrossRef]

73. FAO. Sunflower Crude and Refined Oils. In Agribusiness Handbook; FAO, Ed.; FAO Investment Centre Division: Rome, Italy, 2010.

74. ECN. Phyllis2, Database for (Treated) Biomass, Algae, Feedstocks for Biogas Production and Biochar. ECN. TNO Biomass \& Energy Efficiency. Sunflower Seed Husk (\#378). 2021. Available online: https://www.ecn.nl/phyllis2/Biomass/View/378 (accessed on 5 January 2021).

75. Bhattacharya, S.C.A.S.; Runqing, P.; Somashekar, H.; Racelis, H.I.; Rathnasiri, D.A.; Yingyuad, P.G. An assessment of the potential for non-plantation biomass resources in selected Asian countries for 2010. Biomass Bioenergy 2005, 29, 153-166. [CrossRef]

76. FAO. Official Forestry Data. Food \& Agricultural Organisation to the UN (FAOSTAT). 2021. Available online: http://www.fao. org/faostat/en/\#data/FO (accessed on 5 January 2021).

77. Ngaga, Y.M. Forest Plantations and Woodlots in Tanzania; African Forest Forum Working Paper Series; African Forest Forum: Nairobi, Kenya, 2011; Volume 1, Available online: https:/ /landmatrix.org/media/uploads/sifisewp-contentuploads201202forestplantations-and-woodlots-in-tanzaniapdf.pdf (accessed on 5 January 2021).

78. The Wood Database. Slash Pine I The Wood Database-Lumber Identification. 2021. Available online: http://www.wooddatabase.com/slash-pine/ (accessed on 5 January 2021).

79. The Wood Database. Iroko I The Wood Database-Lumber Identification (Hardwood). 2021. Available online: http://www. wood-database.com/iroko/ (accessed on 5 January 2021).

80. The Wood Database. Caribbean Pine I The Wood Database-Lumber Identification 2021. Available online: http://www.wooddatabase.com/caribbean-pine/ (accessed on 5 January 2021).

81. The Wood Database. Patula Pine / The Wood Database-Lumber Identification. 2021. Available online: http://www.wooddatabase.com/patula-pine/ (accessed on 5 January 2021).

82. The Wood Database. Khasi Pine I The Wood Database-Lumber Identification (Hardwood). 2021. Available online: http: / / www.wood-database.com/khasi-pine/ (accessed on 5 January 2021).

83. The Wood Database. Radiata Pine I The Wood Database-Lumber Identification (Hardwood). 2021. Available online: http: / /www.wood-database.com/radiata-pine/ (accessed on 5 January 2021).

84. The Wood Database. African Juniper I The Wood Database-Lumber Identification (Hardwood). 2021. Available online: http:/ / www.wood-database.com/african-juniper/ (accessed on 5 January 2021).

85. The Wood Database. Mexican Cypress I The Wood Database-Lumber Identification. 2021. Available online: http:/ /www.wooddatabase.com/mexican-cypress / (accessed on 5 January 2021).

86. The Wood Database. Black Wattle I The Wood Database-Lumber Identification. 2021. Available online: http://www.wooddatabase.com/black-wattle/ (accessed on 5 January 2021).

87. The Wood Database. Australian Blackwood I The Wood Database. 2021. Available online: http://www.wood-database.com/ australian-blackwood/ (accessed on 5 January 2021).

88. The Wood Database. Spanish Cedar I The Wood Database-Lumber Identification. 2021. Available online: http://www.wooddatabase.com/spanish-cedar/ (accessed on 5 January 2021).

89. The Wood Database. Camphor I-The Wood Database -Lumber Identification. 2021. Available online: https://www.wooddatabase.com/camphor/ (accessed on 5 January 2021).

90. The Wood Database. River Red Gum I The Wood Database-Lumber Identification. 2021. Available online: http:/ /www.wooddatabase.com/river-red-gum/ (accessed on 5 January 2021).

91. The Wood Database. Blue Gum / The Wood Database-Lumber Identification. 2021. Available online: https://www.wooddatabase.com/blue-gum/ (accessed on 5 January 2021). 
92. The Wood Database. Rose Gum / The Wood Database-Lumber Identification. 2021. Available online: http://www.wooddatabase.com/rose-gum/ (accessed on 5 January 2021).

93. The Wood Database. Southern Silky Oak I The Wood Database-Lumber Identification. 2021. Available online: http://www. wood-database.com/southern-silky-oak/ (accessed on 5 January 2021).

94. The Wood Database. Olive I The Wood Database-Lumber Identification. 2021. Available online: https://www.wood-database. com/olive/ (accessed on 5 January 2021).

95. The Wood Database. Idigbo I The Wood Database-Lumber Identification. 2021. Available online: http://www.wood-database. com/idigbo/ (accessed on 5 January 2021).

96. The Wood Database. Teak / The Wood Database_-Lumber Identification. 2021. Available online: http:/ / www.wood-database. com/teak/ (accessed on 5 January 2021).

97. The Wood Database. Sheoak I The Wood Database. 2021. Available online: http:/ /www.wood-database.com/sheoak (accessed on 5 January 2021).

98. Harris, R.; Phillips, D. Density of Selected Wood Fuels. In Georgia Forestry Comission; Research Division, Georgia Forestry Commission: Macon, GA, USA, 1986.

99. ECN. Phyllis2, Database for (Treated) Biomass, Algae, Feedstocks for Biogas Production and Biochar. Wood, Plywood (\#1487). 2021. Available online: https:/ / www.ecn.nl/phyllis2/Biomass/View/1487 (accessed on 5 January 2021).

100. ECN. Phyllis2, Database for (Treated) Biomass, Algae, Feedstocks for Biogas Production and Biochar. Industrial Wood Waste (\#657). 2021. Available online: https:/ / www.ecn.nl/phyllis2/Biomass/View/ (accessed on 5 January 2021).

101. ECN. Phyllis2, Database for (Treated) Biomass, Algae, Feedstocks for Biogas Production and Biochar. Forest waste (\#312021). 2021. Available online: https:/ / www.ecn.nl/phyllis2/Biomass/View/3121 (accessed on 5 January 2021).

102. ECN. Phyllis2, Database for (Treated) Biomass, Algae, Feedstocks for Biogas Production and Biochar. Wood (\#3116). 2021. Available online: https:/ / phyllis.nl/Browse/Standard/ECN-Phyllis\#3116. (accessed on 5 January 2021).

103. ECN. Phyllis2, Database for (Treated) Biomass, Algae, Feedstocks for Biogas Production and Biochar. Wood, Plywood Scraps (\#443). 2021. Available online: https://www.ecn.nl/phyllis2/Biomass/View/443 (accessed on 5 January 2021).

104. FAO. Official Live Animal Data. Food \& Agricultural Organization to the UN (FAOSTAT). 2021. Available online: http: / / www.fao.org/faostat/en/\#data/QA (accessed on 5 January 2021).

105. Njombe, A.P.; Msanga, Y.; Mbwambo, N.; Makembe, N. The Tanzania Dairy Industry: Status, Opportunities and Prospects. In Proceedings of the 7th African Dairy Conference and Exhibition, MovenPick Palm Hotel, Dar es Salaam, Tanzania, 25-27 May 2011; United Republic of Tanzania, Ministry of Livestock and Fisheries Development: Dar es Salaam, Tanzania, 2011.

106. Shane, A.; Gheewala, S.H.; Phiri, S. Rural domestic biogas supply model for Zambia. Renew. Sustain. Energy Rev. 2017, 78, 683-697. [CrossRef]

107. Bhattacharya, S.C.T.; Jossy, M.; Abdul Salam, P. Greenhouse gas emissions and the mitigation potential of using animal wastes in Asia. Energy 1997, 22, 1079-1085. [CrossRef]

108. Ozcan, M.; Öztürk, S.; Oguz, Y. Potential evaluation of biomass-based energy sources for Turkey. Eng. Sci. Technol. Int. J. 2015, 18, 178-184. [CrossRef]

109. Okello, C.; Pindozzi, S.; Faugno, S.; Boccia, L. Bioenergy potential of agricultural and forest residues in Uganda. Biomass Bioenergy 2013, 56, 515-525. [CrossRef]

110. Msibi, S.S.; Kornelius, G. Potential for domestic biogas as household energy supply in South Africa. J. Energy S. Afr. 2017, 28, 1-13. [CrossRef]

111. Perera, K.K.C.K.; Rathnasiri, P.G.; Senarath, S.A.S.; Sugathapala, A.G.T.; Bhattacharya, S.C.; Abdul Salam, P. Assessment of sustainable energy potential of non-plantation biomass resources in Sri Lanka. Biomass Bioenergy 2005, 29, 199-213. [CrossRef]

112. IBRD-IDA. Urban Population Total in Tanzania. The World Bank Group—DataBank. 2021. Available online: https://data. worldbank.org/indicator/SP.URB.TOTL?locations=CG-TZ (accessed on 5 January 2021).

113. Mwakaje, A.G. Dairy farming and biogas use in Rungwe district, South-west Tanzania: A study of opportunities and constraints. Renew. Sustain. Energy Rev. 2008, 12, 2240-2252. [CrossRef]

114. Orskov, E.R.; Yongabi Anchang, K.; Subedi, M.; Smith, J. Overview of holistic application of biogas for small scale farmers in Sub-Saharan Africa. Biomass Bioenergy 2014, 70, 4-16. [CrossRef] 